\title{
PENINGKATAN HASIL BELAJAR SISWA MATERI JENIS DAN BESAR SUDUT MELALUI MODEL PEMBELAJARAN THINK TALK WRITE (TTW) PADA SISWA KELAS III SDN
}

\author{
Amalia Desi Ambarwati, Zainuddin, Yuniawatika \\ Universitas Negeri Malang \\ e-mail:amaliadesi5@gmail.com
}

\begin{abstract}
Penelitian ini bertujuan untuk mendeskripsikan penerapan model pembelajaran Think Talk Write (TTW) pada dan peningkatan hasil belajar siswa pada materi jenis dan besar sudut pada siswa kelas III SDN Beru 3 Kabupaten Blitar. Hasil penelitian menunjukkan persentase aktivitas guru pada siklus I 79,95\% menjadi $96,65 \%$ kriteria sangat baik pada siklus II. Persentase aktivitas siswa pada siklus I $66,15 \%$ menjadi $85,76 \%$ dengan kriteria baik pada siklus II. Rata-rata nilai hasil belajar siswa pada siklus I 71,31 menjadi 86,49 pada siklus II dengan kriteria baik.
\end{abstract}

Kata kunci: hasil belajar, jenis dan besar sudut, Think Talk Write

Pendidikan merupakan kebutuhan setiap individu. Melalui pendidikan, potensi yang dimiliki oleh setiap individu dapat dikembangkan secara optimal. Potensi yang dimiliki oleh setiap individu tentunya akan berguna di masa yang akan datang. Salah satu tempat untuk memperoleh pendidikan yaitu di Sekolah Dasar (SD). Sekolah Dasar (SD) merupakan satuan pendidikan yang memberikan bekal kemampuan dasar bagi setiap individu. Setiap satuan pendidikan terdapat acuan dalam melaksanakan pendidikan yaitu kurikulum. Sejalan dengan pernyataan Mulyasa (2009: 4) bahwa kurikulum merupakan komponen pendidikan yang dijadikan acuan oleh setiap satuan pendidikan; baik oleh pengelola maupun penyelenggara, khususnya oleh guru dan kepala sekolah. Salah satu mata pelajaran yang ada dalam kurikulum dan diajarkan di sekolah dasar adalah matematika.

Matematika mempunyai peran yang sangat penting dalam kehidupan sehari-hari. Misalnya kegiatan jual beli, mengukur berat benda, mengukur panjang benda, menghitung waktu, menghitung hasil panen, dan lain sebagainya. Untuk itu, matematika perlu diberi- kan sejak dini. Sesuai dengan pendapat Depdiknas (2006: 416) yang menyatakan bahwa mata pelajaran Matematika perlu diberikan kepada semua peserta didik mulai dari sekolah dasar untuk membekali peserta didik dengan kemampuan berpikir logis, analitis, sistematis, kritis, kreatif, dan kemampuan bekerjasama. Namun, pada kenyataannya masih banyak siswa yang mempunyai nilai matematika berada di bawah KKM.

Berdasarkan kenyataan tersebut, guru perlu merancang kegiatan pembelajaran yang menyenangkan. Sehingga siswa dapat mengikuti pembelajaran dengan semangat serta dapat meningkatkan kemampuan pemahaman siswa. Oleh sebab itu, proses pembelajaran matematika yang dilakukan disesuaikan dengan tingkat perkembangan intelektual siswa SD. Menurut Piaget (dalam Heruman, 2014:1) menyatakan bahwa "siswa Sekolah Dasar (SD) umurnya berkisar antara 6 atau 7 tahun, sampai 12 atau 13 tahun. Mereka berada pada fase operasional konkret". Pada fase operasional konkret proses berpikir siswa dalam memecahkan masalah masih tertuju pada hal yang bersifat logika. Siswa masih kesulitan 
untuk berpikir secara abstrak. Sehingga siswa akan lebih paham terhadap suatu konsep apabila dilakukan secara bertahap mulai dari yang mudah ke yang sulit, mulai dari nyata ke abstrak. Menurut Bruner (dalam Muhsetyo, dkk , 2011: 1.12), ada tiga tingkatan yang perlu diperhatikan dalam proses belajar peserta didik, yaitu (a) enactive (memanipulasi objek langsung), (b) iconic (memanipulasi objek tidak langsung), dan (c) symbolic (manipulasi simbol). Dengan kegiatan memanipulasi objek melalui benda nyata yang ada disekitar siswa, maka pembelajaran akan menjadi lebih mudah diingat.

Berdasarkan hasil wawancara yang dilakukan di SDN Beru 3 Kecamatan Wlingi Kabupaten Blitar di kelas III masih banyaknya siswa yang nilainya di bawah KKM dengan nilai KKM sebesar 75. Terdapat 5 siswa $(38,46 \%)$ telah dapat memenuhi nilai KKM yang telah ditentukan, dan masih terdapat 8 siswa $(61,54 \%)$ belum memenuhi KKM yang telah ditentukan. Jumlah siswa kelas III adalah sebanyak 13 siswa, terdiri dari 7 siswa laki-laki dan 6 siswa perempuan.

Pada saat pembelajaran matematika dengan materi jenis dan besar sudut, siswa masih merasa kesulitan untuk mengerjakan soal tentang menuliskan nama sudut. Hal ini dikarenakan siswa belum memahami bahwa dalam menuliskan nama sudut perlu mencantumkan lambang sudut atau menuliskan kata sudut.

Sesuai dengan hasil observasi, permasalahan tersebut terjadi karena pada saat guru menjelaskan materi ada beberapa siswa melakukan kegiatan seperti berbicara dengan temannya, ada siswa yang menyandarkan kepalanya di meja, ada juga siswa yang bermain penggaris saat pembelajaran berlangsung. Padahal guru sudah mengingatkan untuk memperhatikan penjelasan dari guru. Sehingga, pada saat di suruh mengerjakan soal banyak jawaban yang salah. Hal tersebut terjadi karena dalam menjelaskan materi guru menggunakan metode ceramah dan dilanjutkan dengan pemberian tugas. Sehingga pembelajaran berpusat pada guru. Sebagai media, guru hanya membuat gambar sudut di papan tulis dan menuliskan bagian-bagian dari sudut. Pembelajaran dilakukan secara klasikal. Dan berdasarkan hasil wawancara dengan guru kelas, guru belum pernah melakukan pembelajaran secara berkelompok. Sehingga sikap kerja sama dan tanggung jawab siswa belum ditanamkan oleh guru.

Dari data tersebut upaya yang dapat dilakukan untuk meningkatkan hasil belajar siswa sehingga presentase kelulusan dapat meningkat diantaranya (1) pembelajaran sebaiknya melibatkan siswa. Karena dengan keterlibatan siswa dalam proses belajar maka pengetahuan yang diterima oleh siswa akan selalu diingat. Selain itu dengan melibatkan siswa dalam proses pembelajaran bisa menumbuhkembangkan kemampuan pemahaman konsep. (2) Pembelajaran dapat dilakukan secara berkelompok, jadi siswa tidak hanya belajar secara klasikal. Pembelajaran secara berkelompok bisa memberikan kesempatan kepada siswa untuk saling bertukar ide-ide atau informasi. Dengan kegiatan yang beragam, peserta didik akan membangun pengetahuannya sendiri melalui membaca, diskusi, tanya jawab, kerja kelompok, pengamatan, pencatatan, pengerjaan dan presentasi (Muhsetyo, dkk, 2011: 1.11). (3) Siswa SD berada pada tahap operasional konkret, sehingga dalam proses pembelajaran perlu menggunakan media agar materi yang diberikan mudah untuk dipahami.

Dari uraian di atas, maka diperlukan model pembelajaran yang bisa meningkatkan keterlibatan siswa yang dapat menumbuhkan pemahaman melalui kegiatan yang beragam dalam proses pembelajaran agar pembelajaran tidak berpusat pada guru dan menjadi bermakna. Salah satu model pembelajaran yang dapat melibatkan siswa dalam proses pembelajaran yang dapat menumbuhkan pemahaman siswa adalah model pembelajaran Think Talk Write (TTW). Huinker dan Laughlin (dalam Shoimin, 2014: 212) menyatakan bahwa aktifitas yang dapat dilakukan untuk menumbuhkembangkan kemampuan pemahaman konsep dan 
komunikasi peserta didik adalah dengan penerapan pembelajaran Think Talk Write (TTW).

Model pembelajaran Think Talk Write (TTW) merupakan model pembelajaran yang terdiri dari tiga tahap yaitu berpikir, berbicara, dan menulis. Penggunaan model pembelajaran Think Talk Write (TTW) dalam matematika yaitu bisa membantu menumbuhkembangkan pemahaman siswa terhadap suatu konsep matematika. Karena model ini melibatkan siswa secara langsung dalam pembelajaran sehingga siswa bisa membangun pemahaman suatu konsep secara mandiri. Selain itu dengan model pembelajaran Think Talk Write (TTW) siswa diberi kesempatan untuk berbagi ide dalam suatu kelompok untuk menyelesaikan masalah matematika. Kegiatan kelompok juga dapat membantu siswa yang belum bisa dapat bertanya pada siswa yang sudah bisa sehingga terjadi tutor sebaya. Selanjutnya hasil diskusi ditulis dalam lembar kerja siswa dan dipresentasikan di depan kelas. Sehingga kegiatan dalam proses pembelajaran dengan menggunakan model pembelajaran Think Talk Write (TTW) tidak hanya satu atau dua kegiatan melainkan beragam kegiatan.

\section{METODE}

Pendekatan penelitian yang digunakan dalam penelitian ini adalah pendekatan penelitian kualitatif. Jenis penelitian yang digunakan yaitu Penelitian Tindakan Kelas (PTK). Model penelitian yang digunakan menggunakan model spiral yang dikemukakan oleh Kemmis \& M.C Taggart (dalam Arikunto, 2013: 137). Dalam penelitian tindakan kelas terdiri 2 siklus setiap siklus terdiri dari 2 pertemuan. Setiap siklus terdiri dari tahap perencanaan, pelaksanaan, observasi, dan refklesi. Kehadiran peneliti di lapangan yaitu sebagai instrument utama dalam penelitian. Peran peneliti di lapangan yaitu sebagai observer, perencana kegiatan, pelaksana pembelajaran, pengumpul data, menganalisis, dan melaporkan hasil penelitian. Penelitian ini dilaksanakan di SDN Beru 3. Tepatnya di lingkungan Kromasan Kelurahan Beru Kecamatan Wli- ngi Kabupaten Blitar. Subjek penelitian adalah peneliti yang bertindak sebagai guru dan siswa kelas III SDN Beru 3 Kecamatan Wlingi Kabupaten Blitar. Dengan jumlah siswa kelas III adalah 13 siswa yang terdiri 7 siswa laki-laki dan 6 siswa perempuan. Waktu penelitian yaitu tahun ajaran 2016/2017 pada semester II.

Data yang dikumpulkan dalam penelitian ini adalah data proses pelaksanaan pembelajaran dengan menggunakan model pembelajaran Think Talk Write (TTW). Sumber datanya berasal dari peneliti yang bertindak sebagai guru dan siswa kelas III. Selanjutnya yaitu data hasil belajar siswa yang terdiri dari aspek sikap, keterampilan, dan pengetahuan dengan sumber datanya siswa kelas III SDN Beru 3. Pengumpulan data menggunakan obervasi, wawancara, tes, dokumentasi dan catatan lapangan.

Data yang sudah terkumpul selanjutnya dilakukan analisis data. Menurut Suyadi (2010: 85) menyatakan bahwa analisis data adalah mengolah data yang telah terkumpul guna mengetahui seberapa besar keberhasilan tindakan dalam penelitian untuk perbaikan belajar siswa. Terdapat tiga langkah menganalisis data, yaitu (a) reduksi data, (b) penyajian data, dan (c) pemberian kesimpulan.

\section{HASIL}

Hasil belajar siswa pada saat pratindakan memperoleh rata-rata klasikal sebesar 65,76 dengan ketuntasan klasikal sebesar 38,46\% yang artinya terdapat 5 siswa telah tuntas dan 8 siswa belum tuntas KKM dengan kriteria kurang sekali. Pada siklus I pertemuan 1 nilai sikap yang sering muncul adalah 2 sebanyak 9 siswa dan meningkat menjadi nilai 3 sebanyak 6 siswa pada pertemuan 2. Nilai keterampilan pada pertemuan siklus I pertemuan 1 yang tertinggi yaitu 4 sebanyak 4 siswa dan meningkat menjadi 9 siswa pada pertemuan 2. Rata-rata hasil belajar siswa pada siklus I pertemuan 1 sebesar 67,44 dengan ketuntasan klasikal sebesar 38,46\% (5 siswa telah tuntas KKM) dengan kriteria kurang sekali menglami 
peningkatan pada pertemuan 2 dengan ratarata hasil belajar sebesar $75,19 \%$ dengan ketuntasan klasikal sebesar $61,53 \%$ (8 siswa telah tuntas KKM) dengan kriteria kurang. Pada siklus I masih terdapat kekurangankekurangan yang muncul selama pelaksanaan siklus I antara lain: (a) guru masih kurang optimal dalam menerapkan langkah-langkah pembelajaran dengan menggunakan model pembelajaran Think Talk Write (TTW), (b) Siswa masih kebingungan saat membuat catatan tentang hal yang sudah diketahui dan yang belum diketahui dari soal, (c) siswa masih merasa canggung atau malu untuk bertanya, (d) guru masih mendominasi cara mengukur sudut dengan menggunakan busur derajat, (e) dalam kerja kelompok masih belum terlihat kerja sama dalam mengerjakan LKS.

Pelaksaan siklus II berdasrakan dari refleksi siklus I. Hasil belajar siswa pada siklus II sudah mengalami peningkatan. Nilai sikap siswa yang sering muncul menjadi nilai 4 sebanyak 8 siswa pada pertemuan 1 dan meningkat menjadi 11 siswa pada pertemuan 2. Nilai keterampilan siswa juga mengalami peningkatan dari siklus sebelumnya. Nilai keterampilan yang tertinggi yaitu 4 sebanyak 11 siswa pada pertemuan 1 dan meningkat menjadi 12 siswa pada pertemuan 2. Rata-rata hasil belajar siswa pada siklus II pertemuan 1 sebesar 82,97 dengan ketuntasan klasikal sebesar 76,92\% (10 siswa telah tuntas KKM) dengan kriteria cukup menglami peningkatan pada pertemuan 2 dengan rata-rata hasil belajar sebesar 90 dengan ketuntasan klasikal sebesar 92,3\% (12 siswa telah tuntas KKM) dengan kriteria sangat baik. Berdasarkan hasil observasi terdapat peningkatan aktivitas guru dan siswa maupun hasil belajar siswa antara lain: (a) guru sudah menerapkan langkahlangkah pembelajaran dengan menggunakan model pembelajaran Think Talk Write (TTW) dengan baik, (b) siswa tidak lagi merasa kebingungan untuk membuat catatang tentang hal yang sudah diketahui maupun yang belum diketahui dari soal karena sudah terbiasa, (c) siswa sudah tidak malu lagi untuk bertanya tentang materi yang belum dipahami, (d) sifat kerja sama siswa dalam kelompok sudah mulai tampak, (e) guru dapat melaksanakan pembelajaran secara tepat waktu, (f) terjadi peningkatan hasil belajar siswa dari siklus I ke siklus II.

\section{PEMBAHASAN}

\section{Penerapan Model Pembelajaran Think Talk Write (TTW) Untuk Meningkatkan Hasil Belajar Siswa Tentang Jenis dan Besar Sudut di Kelas III SDN Beru 3}

Penerapan model pembelajaran Think Talk Write (TTW) dapat dilaksankan dengan baik. Hasil temuan aktivitas guru pada siklus I maupun siklus II guru membuka pembelajaran dengan salam, do'a, dan presensesi. Selanjutnya guru melakukan apersepsi, hal ini bertujuan untuk menggali pengetahuan awal siswa. Dan dilanjutkan dengan menyampaikan informasi dan tujuan dari materi yang akan dibahas.

Kegiatan inti diawali dengan guru membagikan sebuah LKS yang berisi tentang permasalahan yang harus dikerjakan oleh setiap siswa. Selanjutnya, sebelum mengerjakan LKS siswa diminta untuk membuat catatan dari permasalahan tentang hal yang sudah diketahui dan belum diketahui (think). Setelah semua siswa selesai membuat catatan, guru membentuk siswa menjadi 4 kelompok masing-masing kelompok terdiri dari 3-4 siswa. Kegiatan yang dilakukan dalam kelompok yaitu mendiskusikan catatan yang telah dibuat dengan teman satu kelompoknya (talk). Setelah itu siswa menuliskan hasil diskusi sebagai jawaban atas permasalahan yang ada pada LKS (write). Kemudian, perwakilan kelompok maju ke depan kelas untuk menyampaikan hasil diskusi sedangkan siswa lainnya memperhatikan dan memberi tanggapan. Setelah itu, perwakilan siswa maju ke depan untuk menyampaikan kesimpulan dari pembelajaran yang telah dilakukan dan dilanjutkan dengan guru melakukan refleksi.

Pada saat pelaksanaan siklus I pertemuan 1 guru memberikan sebuah LKS yang 
berisi tentang konsep sudut. Di dalam LKS, siswa diminta untuk menyiapkan sebuah lidi yang digunakan sebagai media pembelajaran. Lidi tersebut digabungkan membentuk sebuah sudut. Selanjutnya siswa diminta untuk menggambarkannya di kotak yang sudah di sediakan dalam LKS. Setelah itu, siswa diminta untuk menyimpulkan pengertian sudut dari kegiatan yang telah dilakukan. Pada permasalahan berikutnya, siswa diminta untuk menuliskan lambang sudut. Kegiatan ini sesuai dengan pendapat Bruner (dalam Muhsetyo, dkk , 2011: 1.12), ada tiga tingkatan yang perlu diperhatikan dalam proses belajar peserta didik, yaitu (a) enactive (memanipulasi objek langsung), (b) iconic (memanipulasi objek tidak langsung), dan (c) symbolic (manipulasi simbol).

Pada saat pelaksaan siklus I pertemuan 1 berlangsung, siswa masih kebingungan untuk membuat catatan. Pada tahap membuat catatan memerlukan waktu yang cukup lama dan guru tidak sempat melakukan kegiatan membuat kesimpulan. Selain itu, siswa juga masih belum menunjukkan perilaku saling bertanya atau berpendapat dalam berkelompok. Siswa masih takut untuk menyampaikan hasil diskusi di depan kelas. Hal ini berpengaruh pada nilai aktivitas guru dan siswa pada siklus I pertemuan 1. Guru mendapat presentase ketuntasan $73,3 \%$ mendapat kriteria tingkat keberhasilan "cukup" dan presentase ketuntasan aktivitas siswa 63,63\% mendapat kriteria tingkat keberhasilan "kurang".

Pada siklus I pertemuan 2 aktivitas guru dan siswa telah mengalami peningkatan. Siswa sudah mulai bisa membuat catatan tentang permasalahan nama sudut dalam sebuah bangun datar, mengukur besar sudut, dan mengurutkan besar sudut tanpa bimbingan, hanya beberapa siswa saja yang masih perlu bimbingan. Presentase keberhasilan ketuntasan aktivitas guru mencapai $86,6 \%$ dengan kriteria tingkat keberhasilan "baik" dan presentase ketuntasan aktivitas siswa mencapai $74,82 \%$ mendapat kriteria tingkat keberhasilan "cukup".
Pada siklus II siswa sudah mulai terbiasa membuat catatan. Sehingga pembelajaran dapat berjalan dengan lancar. Siswa sudah bisa membuat catatan dari permasalahan tentang jenis-jenis sudut. Siswa juga sudah dapat bekerja sama bersama anggota kelompoknya dengan bertanya maupun berpendapat. Siswa sudah memiliki sikap percaya diri, hal ini ditunjukkan dengan adanya siswa yang saling berebut untuk maju ke depan untuk menyampaikan hasil diskusi. Sehingga pada siklus II terjadi peningkatan hasil aktivitas guru maupun siswa. Pada siklus II pertemuan 1 presentase aktivitas guru mencapai 93,3\% dengan kriteria tingkat keberhasilan "sangat baik" dan presentase aktivitas siswa mencapai $83,21 \%$ dengan kriteria tingkat keberhasilan "baik". Selanjutnya pada siklus II pertemuan 2 siswa sudah bisa membuat catatan tentang sudut sebagai jarak putar. Siswa sudah menunjukkan sikap percaya diri yang tinggi, siswa yang tadinya tidak mau maju kedepan sudah berani tampil di depan kelas. Siswa yang tadinya tidak berani bertanya pada guru menjadi berani bertanya pada guru. Hasil presentase aktivitas guru pada siklus II pertemuan 2 mencapai 100\% dengan kriteria tingkat keberhasilan "sangat baik" dan presentase aktivitas siswa mencapai 90,9\% dengan kriteria tingkat keberhasilan "sangat baik".

Penerapan model pembelajaran Think Talk Write (TTW) dalam pembelajaran menunjukkan bahwa pembelajaran tidak hanya berpusat pada guru, siswa menjadi aktif di dalam kelas, siswa menjadi berani tampil di depan kelas, siswa menjadi berani untuk bertanya maupun berpendapat dengan siswa lain dan guru. Hal ini menunjukkan bahwa model pembelajaran Think Talk Write (TTW) memiliki kelebihan sebagaimana yang diungkapkan oleh Shoimin (2014: 215) adalah sebagai berikut: (a) Mengembangkan pemecahan yang bermakna dalam memahami materi ajar. (b) Dengan memberikan soal open ended dapat mengembangkan keterampilan berpikir kritis dan kreatif siswa. (c) Dengan 
berinteraksi dan berdiskusi dengan kelompok akan melibatkan siswa secara aktif dalam belajar. (d) Membiasakan siswa berpikir dan berkomunikasi dengan teman, guru, bahkan dengan diri mereka sendiri.

Peningkatan tersebut menunjukkan bahwa penerapan model pembelajaran Think Talk Write (TTW) dalam pembelajaran matematika materi jenis dan besar sudut dapat meningkatkan aktiviatas guru maupun aktivitas siswa di SDN Beru 3 Kabupaten Blitar.

\section{Peningkatan Hasil Belajar Siswa Jenis dan Besar Sudut pada Siswa Kelas III SDN Beru 3}

Hasil belajar siswa materi jenis dan besar sudut yang dicapai siswa mengalami peningkatan mulai dari pratindakan, siklus I, dan siklus II. Hasil belajar siswa terdiri dari penilaian sikap, penilaian keterampilan, dan penilaian pengetahuan. Pada pratindakan rata-rata hasil belajar adalah 65,76 dengan ketuntasan klasikal sebesar 38,46\% (5 siswa tuntas belajar) dengan kriteria kurang sekali.

Pada siklus I pertemuan 1 nilai sikap siswa yang mendapat nilai yang sering muncul adalah 2 sebanyak 9 siswa dengan deskripsi sikap kerja sama, tanggung jawab, dan percaya diri siswa mulai terlihat dan penilaian keterampilan yang mendapat skor tertinggi 4 sebanyak 4 siswa dengan deskripsi siswa dapat mengukur besar sudut, menggambar sudut, dan membuat catatan dengan sangat baik. Penilaian hasil belajar pengetahuan memeperoleh rata-rata nilai 67,44. Presentase ketuntasan klasikal sebesar 38,46\% yang artinya ada 5 siswa yang mendapat nilai diatas KKM dan masih ada 8 siswa yang nilainya di bawah KKM. Pada siklus I pertemuan 2, terjadi peningkatan nilai sikap siswa dari yang sebelumnya modus nilai 2 menjadi modus nilai 3 sebanyak 6 siswa dengan deskripsi sikap kerja sama, tanggung jawab, dan percaya diri siswa mulai berkembang. Selanjutnya, nilai keterampilan siswa juga mengalami peningkatan perolehan skor tertinggi 4 sebanyak 9 siswa. Nilai hasil belajar mendapat rata-rata sebesar 75,19 dengan ketuntasan klasikal sebesar 61,53\% yang berarti ada 8 siswa telah mencapai KKM dan masih ada 5 siswa yang belum mencapai KKM.

Pada siklus II hasil belajar siswa juga mengalami peningkatan dari pertemuan $1 \mathrm{ke}$ pertemuan 2. Pada siklus II pertemuan 1, penilaian sikap siswa yang yang sebelumnya modus nilai 3 menjadi modus nilai 4 sebanyak 8 siswa dengan deskripsi sikap kerja sama, tanggung jawab, dan percaya diri siswa sudah berkembang. Penilaian keterampilan siswa yang mendapat skor tertinggi 4 sebanyak 11 siswa dengan deskripsi siswa dapat mengukur besar sudut, menggambar sudut, dan membuat catatan dengan sangat baik. Penilaian hasil belajar pengetahuan pertemuan 2 memperoleh rata-rata $82,97 \%$ dengan ketuntasan klasikal sebesar 76,92\% yang berarti ada 10 siswa telah mencapai KKM. Pada siklus II pertemuan 2 peningkatan penilaian sikap yang mendapat modus skor 4 sebanyak 11 siswa. Peningkatan nilai sikap disebabkan adanya motivasi yang diberikan oleh guru maupun motivasi yang berasal dari diri siswa. Penilaian keterampilan siswa pada siklus II pertemuan 2 yang mendapat skor tertinggi 4 ada 12 siswa. Peningkatan nilai keterampilan disebabkan karena siswa sudah terbiasa melakukan kegiatan mengukur sudut, menggambar sudut, dan membuat catatan. Penilaian hasil belajar pengetahuan pada siklus II pertemuan 2 memperoleh rata-rata nilai sebesar 90 dengan ketuntasan klasikal sebesar $92,3 \%$ yang berarti ada 12 siswa telah mencapai KKM dan hanya ada 1 siswa yang belum mencapai KKM. Hal ini dikarenakan siswa tersebut lamban dalam menyerap materi dan masih kesulitan dalam membaca bacaan. Peningkatan penilaian hasil disebabkan karena siswa sudah berani bertanya jika menemui kesulitan sehingga guru bisa memberi penjelasan secara mendalam.

Berdasarkan data tersebut, diperoleh data pada siklus II sudah mencapai target ketuntasan minimal klasikal yaitu sudah melebihi $80 \%$ yaitu sebesar $92,3 \%$. Hal tersebut sesuai dengan pendapat Sudjana (2009: 8), ketun- 
tasan belajar secara klasikal dikatakan tuntas jika $80 \%$ siswa dalam kelas mendapat nilai lebih besar atau sama dengan KKM (75). Sehingga, penelitian ini dapat dikatakan sudah tuntas dan tidak dilanjutkan pada siklus selanjutnya. Dengan demikian model pembelajaran Think Talk Write (TTW) dapat meningkatkan hasil belajar siswa pada pembelajaran matematika materi jenis dan besar sudut pada siswa kelas III SDN Beru 3 Kabupaten Blitar.

\section{PENUTUP}

\section{Kesimpulan}

Penerapan model pembelajaran Think Talk Write (TTW) terdiri dari (a) guru membagikan LKS, (b) kegiatan think, (c) membentuk kelompok, (d) kegiatan talk, (e) kegiatan write, (f) menyampaikan hasil diskusi, (g) membuat kesimpulan dan refleksi dilakukan dengan baik terlihat dari nilai aktivitas guru pada siklus I ke siklus II mengalami peningkatan.

Peningkatan hasil belajar jenis dan besar sudut pada siswa kelas III SDN Beru III dengan penerapan model pembelajaran Think Talk Write (TTW) sudah baik. Modus nilai sikap siswa yang semula 2 dengan deskripsi mulai terlihat menjadi nilai 4 dengan deskrispi sudah berkembang. Nilai keterampilan siswa mendapat skor 4 dengan deskrispi dapat mengukur besar sudut, menggambar sudut dan membuat catatan dengan sangat baik dari siklus I pertemuan 1 sebanyak 4 menjadi 12 pada siklus II pertemuan 2. Rata-rata nilai pengetahuan pada siklus I sebesar 72,89 meningkat menjadi 88,19 pada siklus II. Persentase ketuntasan klasikal yang dicapai pada siklus I pertemuan 1 mencapai $38,46 \%$ ( 5 siswa tuntas belajar) kriteria kurang sekali dan siklus II pertemuan 2 mencapai 92,3\% (12 siswa tuntas belajar) kriteria sangat baik .

\section{Saran}

Saran dari pembelajaran matematika melalui model pembelajaran Think Talk Write (TTW) pada siswa kelas III di SDN Beru III Kabupaten Blitar, yaitu: bagi peneliti lanjutan, semoga hasil penelitian ini dapat digunakan sebagai informasi dalam mengadakan penelitian-penelitian selanjutnya dengan menggunakan model pembelajaran Think Talk Write (TTW).

Bagi guru, dengan menerapkan model pembelajaran Think Talk Write (TTW) dapat dijadikan sebagai salah satu solusi untuk meningkatkan kualitas pembelajaran matematika di SD dan hasil belajar siswa.

Bagi siswa, lebih termotivasi dalam mengikuti proses pembelajaran khususnya pada mata pelajaran matematika dengan menggunakan model pembelajaran Think Talk Write (TTW).

Bagi sekolah, dapat digunakan sebagai salah satu masukan dalam memperbaiki pembelajaran dan mengatasi masalah yang ada dalam kelas dengan menggunakan model pembelajaran Think Talk Write (TTW) khususnya pada mata pelajaran matematika.

\section{DAFTAR RUJUKAN}

Arikunto, Suharsimi. 2013. Prosedur Penelitian Suatu Pendekatan Praktik. Jakarta: PT Rineka Cipta.

Depdiknas. 2006. Standar Kompetensi Dan Kompetensi Dasar BSNP. Jakarta: Badan Standar Nasional Indonesia.

Heruman. 2014. Model Pmbelajaran Matematika Di Sekolah Dasar. Bandung: PT Remaja Rosdakarya Offset.

Muhsetyo, Gatot, dkk. 2011. Pembelajaran Matematika SD. Jakarta: Universitas Terbuka.

Mulyasa. 2009. Kurikulum Tingkat Satuan Pendidikan Sebuah Panduan Praktis. Bandung: PT Remaja Rosdakarya Offset. Shoimin, Aris. 2014. 68 Model Pembelajaran Inovatif dalam Kurikulum 2013. Yogyakarta: Ar-Ruzz Media.

Sudjana, Nana. 2009. Penilaian Hasil Proses Belajar Mengajar. Bandung: PT Remaja Rosdakarya.

Suyadi. 2010. Panduan Penelitian Tindakan Kelas. Jogjakarta: Diva Press 